\title{
Isolation and characterisation of crocodile and python ovotransferrins
}

\author{
Justyna Ciuraszkiewicz, Mariusz Olczak and Wiesław Wątorek ${ }^{\bowtie}$ \\ Laboratory of Biochemistry, Faculty of Biotechnology, University of Wroclaw, Wrocław, Poland
}

Received: 28 November, 2006; revised: 12 February, 2007; accepted: 16 February, 2007

available on-line: 09 March, 2007

\begin{abstract}
Transferrins play a major role in iron homeostasis and metabolism. In vertebrates, these proteins are synthesised in the liver and dispersed within the organism by the bloodstream. In oviparous vertebrates additional expression is observed in the oviduct and the synthesised protein is deposited in egg white as ovotransferrin. Most research on ovotransferrin has been performed on the chicken protein. There is a limited amount of information on other bird transferrins, and until our previous paper on red-eared turtle protein there was no data on the isolation, sequencing and biochemical properties of reptilian ovotransferrins. Recently our laboratory deposited ten new sequences of reptilian transferrins in the EMBL database. A comparative analysis of these sequences indicates a possibility of different mechanisms of iron release among crocodile and snake transferrin. In the present paper we follow with the purification and analysis of the basic biochemical properties of two crocodile (Crocodilus niloticus, C. rhombifer) and one snake (Python molurus bivittatus) ovotransferrins. The proteins were purified by anion exchange and hydrophobic chromatography, and their N-terminal amino-acid sequences, molecular mass and isoelectric points were determined. All three proteins are glycosylated and their N-glycan chromatographic profiles show the largest contribution of neutral oligosaccharides in crocodile and disialylated glycans in python ovotransferrin. The absorption spectra of iron-saturated transferrins were analysed. Iron release from these proteins is $\mathrm{pH}$-dependent, showing a biphasic character in crocodile ovotransferrins and a monophasic type in the python protein. The reason for the different types of iron release is discussed.
\end{abstract}

Keywords: crocodile, Crocodylus niloticus, Crocodylus rhombifer, iron release, N-glycans, ovotransferrin, python, Python molarus bivittatus

\section{INTRODUCTION}

Iron plays a crucial role in many cellular functions, such as oxygen transport and mitochondrial energy metabolism. For this reason iron deficiency is hazardous to organisms. Its overload is also undesirable on account of its favouring toxic free radical formation (Hentze \& Kühn, 1996; Aisen et al., 2001). One of the most important agents in iron homeostasis and metabolism is the iron-binding protein transferrin. Transferrins are widely distributed among vertebrates as well as invertebrates (Lambert et al., 2005b). They are involved mainly in ferric ion acquisition, transport, and level control, but also in antimicrobial defence and in cell growth and differentiation (for a review, see Gomme \& Mc Cann, 2005).

Vertebrate transferrins include serotransferrins, lactoferrins, and ovotransferrins. In mammals, the dual role of transferrin (iron transport and scavenging) is divided between serotransferrin and lactoferrin. The first transports iron through the bloodstream and delivers it from places of assimilation (e.g., intestine) to places of utilization (e.g., bone marrow) (Bailey et al., 1988). The second captures free ferric ions in mammalian body secretions, thereby sequestering the metal from invading microorganisms (Valenti \& Antonini, 2005).

\footnotetext{
$\square$ Corresponding author: Wiesław Wątorek, Laboratory of Biochemistry, Faculty of Biotechnology, University of Wroclaw, Tamka 2, 50-137 Wrocław, Poland; phone: (48 71) 375 2712; fax: (48 71) 375 2608; e-mail: watorek@biotech.uni.wroc.pl Abbreviations: 2-AB, 2-aminobenzamide; CBB R-250, Coomassie Brilliant Blue R-250; FPLC, fast protein liquid chromatography; MALDI-TOF MS, matrix assisted laser desorption ionisation-time of flight mass spectrometry; PNGase F, peptide: $N$-glycosidase F.
} 
In birds there is only one transferrin gene, expressed in the liver and in the oviduct. The hepatocyte-derived protein is delivered to the bloodstream similarly as mammalian serotransferrin, while the protein synthesised in tubular gland cells is deposited in egg white as ovotransferrin (Lee et al., 1980). A similar situation probably also exists in reptiles (Ciuraszkiewicz et al., 2006).

Transferrins are monomeric glycoproteins with molecular mass of about $80 \mathrm{kDa}$. Contemporary transferrins originated by gene duplication and fusion of a single-lobe ancestor protein, resulting in a bilobal structure (Park et al., 1985). The N- and Clobes are about $40 \%$ homologous and each contains two domains (NI and NII, and CI and CII) separated by a hydrophilic cleft where the iron-binding site is located (Baker et al., 2003). The ferric ions in both lobes are coordinated by a carboxylate oxygen of an Asp residue, two phenolate oxygens of two Tyr residues, and the imidazole nitrogen of one His residue. The two remaining coordination sites are occupied by two oxygen atoms from a synergistically bound carbonate anion, anchored in the protein by Arg and Thr residues (Baker et al., 2001).

Transferrins bind and release ferric ion in a $\mathrm{pH}$-dependent manner. They have the capacity to uptake $\mathrm{Fe}^{3+}$ with a very high affinity at near-neutral $\mathrm{pH}$ and to release it at acidic conditions. In vivo, iron-loaded transferrin binds at a slightly basic $\mathrm{pH}$ ( $\mathrm{pH}$ 7.4) to cell membrane transferrin receptor. The transferrin-receptor complex is subsequently transferred to acidic endosomes $(\mathrm{pH}$ 5.5) where ferric ions are released from the protein (Gianetti et al., 2005).

Despite identical ligands in both lobes there are differences in the rate of iron release from the $\mathrm{N}$ - and C-lobes within a specific type of transferrin (Mason et al., 2005) and between different transferrins (sero-, lacto-, and ovotransferrins) (Baker et al., 2002). Our knowledge of the mechanism of iron binding and release by transferrin is based on seqences and structural data obtained only for a few mammalian sero- and lactoferrins and hen and duck ovotransferrins (Baker et al., 2002). Many details of this mechanism are still unclear. To respond to some unresolved questions, it is necessary to perform comparative functional and structural analyses of transferrins from different animal species. More than 70 sequences are now available for alignment (Lambert et al., 2005a), but only one of reptilian origin (Ciuraszkiewicz et al., 2006). Recently we have deposited ten reptilian transferrin cDNA sequences in the EMBL database, among them the Nile crocodile (AM262323) and Burmese python (AM262317) sequences. A comparative analysis of these sequences indicates a possibility of different mechanisms of iron release from the N-lobes among crocodile and snake transferrin. To prove it experimentally we follow in this paper with a description of the isolation and properties of ovotransferrins from two crocodile and one snake species.

\section{MATERIALS AND METHODS}

Animal material. Eggs of the Nile crocodile (Crocodylus niloticus), Cuban crocodile (C. rhombifer) and Burmese python (Python molurus bivittatus) were obtained from the zoological gardens in Wroclaw and Warsaw (Poland).

Purification of ovotransferrins from crocodile eggs. The crocodile egg whites separated from the yolk and shell were lyophilised, suspended in $0.05 \mathrm{M}$ sodium phosphate buffer, $\mathrm{pH} 7.0$, containing $0.15 \mathrm{M} \mathrm{NaCl}$, and then centrifuged $(20000 \times \mathrm{g}$, $10 \mathrm{~min}, 4^{\circ} \mathrm{C}$ ). The supernatants were fractionated using $30 \%, 50 \%$, and finally $80 \%$ ammonium sulphate saturation. Following dialysis against $0.02 \mathrm{M}$ Tris/ $\mathrm{HCl}$ buffer, $\mathrm{pH}$ 8.5, the solutions of proteins obtained in the last step of precipitation were applied on a chromatographic column. The purification procedure included anion exchange chromatography and hydrophobic chromatography. Anion exchange chromatography was performed using a MonoQ HR 5/5 column and a fast protein liquid chromatography (FPLC) system (Pharmacia). The column was equilibrated with $0.02 \mathrm{M}$ Tris $/ \mathrm{HCl}$ buffer, $\mathrm{pH}$ 8.5. Fractions of $1 \mathrm{ml}$ were collected at a flow rate of $1 \mathrm{ml} / \mathrm{min}$. Proteins were eluted with $\mathrm{NaCl}$ gradient $(0-1.0 \mathrm{M})$ with a total gradient volume of $30 \mathrm{ml}$. Hydrophobic chromatography was carried out on a PhenylSuperose HR 5/5 column (Pharmacia) using the FPLC system. The column was equilibrated with $0.05 \mathrm{M}$ sodium phosphate buffer, $\mathrm{pH} 7.0$, containing $1.7 \mathrm{M}\left(\mathrm{NH}_{4}\right)_{2} \mathrm{SO}_{4}$. Fractions of $1 \mathrm{ml}$ were collected at a flow rate of 0.5 $\mathrm{ml} / \mathrm{min}$. Proteins were eluted with $\left(\mathrm{NH}_{4}\right)_{2} \mathrm{SO}_{4}$ gradient $(1.7-0 \mathrm{M})$ with a total gradient volume of 21 $\mathrm{ml}$.

Purification of ovotransferrins from python eggs. Python ovotransferrin was isolated from egg yolk and white using the Kim and Nakai modified method (1996) as a first step. Briefly, egg yolk and white were diluted 10 times with distilled water, adjusted to $\mathrm{pH} 5.0$ with $0.1 \mathrm{M} \mathrm{HCl}$, kept for $2 \mathrm{~h}$ at $4^{\circ} \mathrm{C}$, frozen at $-20^{\circ} \mathrm{C}$ for at least $24 \mathrm{~h}$, then slowly thawed at $4^{\circ} \mathrm{C}$ overnight, and finally filtered and centrifuged $\left(20000 \times \mathrm{g}, 20 \mathrm{~min}, 4^{\circ} \mathrm{C}\right)$. The supernatant was fractionated using $30 \%, 50 \%$, and finally $80 \%$ ammonium sulphate saturation. The final pellet was dissolved and dialysed against $0.02 \mathrm{M}$ Tris/ $\mathrm{HCl}$ buffer, $\mathrm{pH}$ 8.5, and applied on a MonoQ HR 5/5 column equilibrated with the same buffer. Fractions of $1 \mathrm{ml}$ were collected at a flow rate of $1 \mathrm{ml} / \mathrm{min}$. Proteins 
were eluted with $\mathrm{NaCl}$ gradient $(0-1.0 \mathrm{M})$ with a total gradient volume of $26 \mathrm{ml}$.

Determination of protein concentration. Protein concentration was determined by the modified Bradford method (Zor \& Selinger, 1996) using Roti reagent (Roth) and bovine serum albumin as a standard.

Polyacrylamide gel electrophoresis. SDS/ PAGE was carried out in $10 \%(\mathrm{w} / \mathrm{v})$ or in gradient $4-16 \%(w / v)$ gel by the method of Schägger and von Jagow (1987). Proteins were stained with CBB R-250.

Amino-acid sequence analysis. After SDS/ PAGE, Nile crocodile and python proteins were transferred onto polyvinylidene fluoride membrane (Bio-Rad) in $10 \mathrm{mM}$ Caps buffer, $\mathrm{pH}$ 11.0, with 10\% $(\mathrm{v} / \mathrm{v})$ methanol for $1.5 \mathrm{~h}$ at a constant current of $0.15 \mathrm{~A}$ and subjected to amino-acid sequence analysis on a gas-phase sequencer (Model 491, Perkin Elmer-Applied Biosystems) (BioCenter of Jagiellonian University, Kraków, Poland). The phenylthiohydantoin derivatives were analysed by on-line gradient high-performance liquid chromatography on a Microgradient Delivery System Model 140C equipped with a Programmable Absorbance Detector Model 785A (both from Perkin Elmer-Applied Biosystems).

Determination of molecular mass. Molecular mass was determined using SDS/PAGE and mass spectrometric analyses. SDS/PAGE was carried out in gradient $4-16 \%(\mathrm{w} / \mathrm{v})$ gel by the method of Schägger and von Jagow (1987). Proteins were stained with CBB R-250. Mass spectrometric analysis was performed with a MALDI-TOF Reflex IV mass spectrometer (Bruker-Daltonics) (Neurobiochemistry Unit, Faculty of Chemistry, Jagiellonian University, Kraków, Poland). Samples were dissolved in a methanol/water mixture $(3: 7, \mathrm{v} / \mathrm{v})$ and mixed with an equal volume of saturated matrix solution (sinapinic acid dissolved in a water/acetonitrile mixture, $1: 2, \mathrm{v} / \mathrm{v})$. After mixing, $1 \mu \mathrm{l}$ of the prepared sample was applied on a steel plate and left to dry. The plate with the dried sample was inserted into the spectrometer. The scan range was set to $10-200$ $\mathrm{kDa}$. The mass spectrometer was calibrated according to the standard procedure using Bruker's calibration mixture.

Determination of isoelectric points of transferrins. To determine the isoelectric points of the investigated proteins, chromatofocusing separations on a Mono P HR 5/20 column (Pharmacia) were performed. Lyophilised, purified and desalted protein samples (about $100 \mu \mathrm{g}$ ) were resolved in the respective starting buffer as stated below. The chromatography in $\mathrm{pH}$ gradient was performed at a flow rate of $1 \mathrm{ml} / \mathrm{min}$. The $\mathrm{pH}$ interval for crocodile transferrins was from 7 to 5 with $0.025 \mathrm{M}$ bis-Tris $/ \mathrm{HCl}, \mathrm{pH}$ 7.1 , as a starting buffer and Polybuffer $74 / \mathrm{HCl}, \mathrm{pH}$
5.0, as eluent. For python transferrin pI determination, the $\mathrm{pH}$ interval was from 6 to 4 with $0.025 \mathrm{M}$ bis-Tris/ $\mathrm{HCl}, \mathrm{pH} 6.3$, as a starting buffer and Polybuffer $74 / \mathrm{HCl}, \mathrm{pH} 4.0$, as an eluent. Fractions (1.0 $\mathrm{ml})$ were monitored spectrophotometrically at 280 $\mathrm{nm}$. The $\mathrm{pH}$ of each collected fraction was measured using a Metrohm $691 \mathrm{pH}$ Meter. The purity of samples containing eluted proteins was additionally checked by SDS/PAGE.

N-glycan profiling. Deglycosylation was carried out with PNGase F (Boehringer Mannheim Biochemicals). Ten micrograms of the denatured (unfolded) protein was incubated with 7 units of PNGase $\mathrm{F}$ at $37^{\circ} \mathrm{C}$ for $20 \mathrm{~h}$. Glycans were isolated using GlycoClean H SPE cartridges (Oxford GlycoSciences) according to the manufacturer's protocol. The reducing ends of the oligosaccharides were fluorescently labelled with 2-AB (Sigma) according to the Bigge method (1995). Labelled glycans were purified with GlycoClean S columns (Oxford GlycoSciences) according to the manufacturer's recommendation. Oligosaccharide analysis was performed on an ion exchange column (GlycoSep C, $250 \times 4.6 \mathrm{~mm}$, Oxford GlycoSciences) by high-performance liquid chromatography on a Knauer apparatus with Shimadzu RF-551 fluorescence detector $\left(\lambda_{\text {excitation }}=330 \mathrm{~nm}\right.$ and $\lambda_{\text {emission }}$ $=420 \mathrm{~nm})$. Gradient conditions were as follows: buffer $\mathrm{A}-20 \%(\mathrm{v} / \mathrm{v})$ acetonitrile in water and buffer B $-0.25 \mathrm{M}$ ammonium formate in $20 \%$ (v/ v) acetonitrile, $\mathrm{pH} 4.5,(0-70 \mathrm{~min}, 35-50 \%$ buffer B; $70-71 \mathrm{~min}, 50-100 \%$ buffer B; $71-80 \mathrm{~min}, 100 \%$ buffer B). The total gradient volume was $32 \mathrm{ml}$ at a flow rate of $0.4 \mathrm{ml} / \mathrm{min}$.

Absorption spectra of iron-saturated transferrins. Purified transferrins were dialysed against 0.1 $\mathrm{M}$ Tris/ $\mathrm{HCl}$ buffer, $\mathrm{pH} 8.5$, containing $5 \mathrm{mM} \mathrm{Na}_{2} \mathrm{CO}_{3}$ and saturated with iron by incubating overnight at $10^{\circ} \mathrm{C}$ with $\mathrm{FeCl}_{3}$ at a molar ratio of $1: 4$. Excess iron was removed by dialysing the iron-saturated proteins against $0.1 \mathrm{M}$ Tris/ $\mathrm{HCl}$ buffer, $\mathrm{pH} 8.5$, containing $0.15 \mathrm{M} \mathrm{NaCl}$. Absorption spectra were recorded for $1.9 \mathrm{mg} / \mathrm{ml}$ protein solutions over the range of 400-560 nm using a Beckman DU 640 Spectrophotometer.

The $\mathrm{pH}$-dependent iron release. The $\mathrm{pH}$-dependent iron release was monitored following dialysis of the protein solution against a series of buffers over the $\mathrm{pH}$ range $3.5-8.5$, each containing $0.15 \mathrm{M}$ $\mathrm{NaCl}$. The buffers used for these experiments were: $0.05 \mathrm{M}$ Tris $/ \mathrm{HCl}$ in the $\mathrm{pH}$ range 7.0-8.5, $0.05 \mathrm{M}$ Mes $/ \mathrm{NaOH}$ in the $\mathrm{pH}$ range $6.0-6.5,0.05 \mathrm{M}$ sodium acetate buffer in the $\mathrm{pH}$ range $4.0-5.5$, and $0.05 \mathrm{M}$ glycine $/ \mathrm{HCl}$ buffer at $\mathrm{pH} 3.5$. At each $\mathrm{pH}$ value the percentage of iron saturation was estimated assuming $\mathrm{A}_{465} / \mathrm{A}_{280}$ at $\mathrm{pH} 8.5$ as $100 \%$ and at $\mathrm{pH} 3.5$ as $0 \%$ iron saturation. 
A)

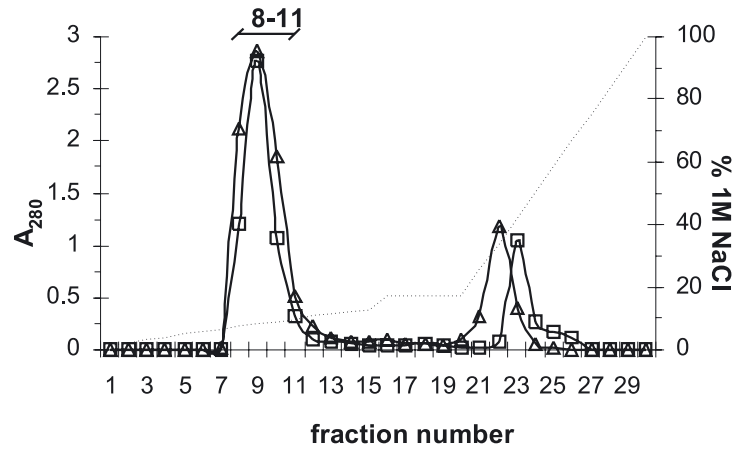

B)

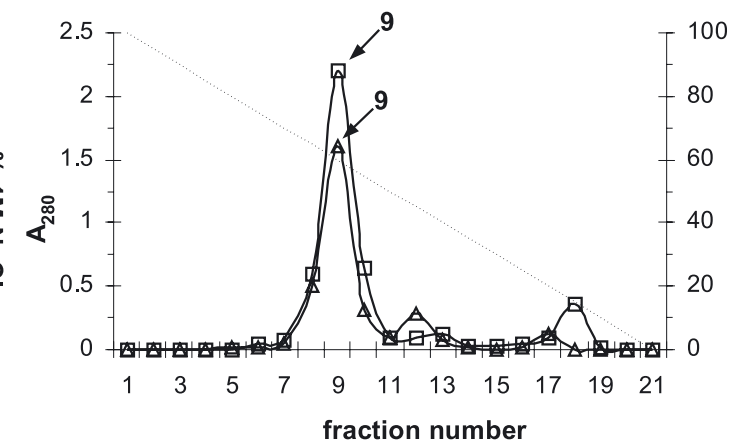

Figure 1. Chromatography of crocodile egg white proteins.

Cuban $(\square)$ and Nile $(\Delta)$ crocodile egg white proteins were purified by ion-exchange chromatography on a MonoQ HR $5 / 5$ column (A) and hydrophobic chromatography on a PhenylSuperose HR 5/5 column (B). About $10 \mathrm{mg}$ of protein in $0.02 \mathrm{M} \mathrm{Tris} / \mathrm{HCl}$ buffer, $\mathrm{pH} 8.5$, was applied on a MonoQ column equilibrated with the same buffer. Proteins were eluted with a nonlinear gradient from 0 to $1 \mathrm{M} \mathrm{NaCl}(30 \mathrm{ml})$ at a flow rate of $1 \mathrm{ml} / \mathrm{min}$ (fraction volume: $1 \mathrm{ml})$. Pooled fractions (marked) were applied on a PhenylSuperose HR 5/5 column equilibrated with $0.05 \mathrm{M}$ sodium phosphate buffer, $\mathrm{pH}$ 7.0, containing $1.7 \mathrm{M}\left(\mathrm{NH}_{4}\right)_{2} \mathrm{SO}_{4}$. A solution containing $5.2 \mathrm{mg}$ of protein in starting buffer was applied on the column. Proteins were eluted with $\left(\mathrm{NH}_{4}\right)_{2} \mathrm{SO}_{4}$ gradient $(1.7-0 \mathrm{M})$ with a total gradient volume of $21 \mathrm{ml}$. Fractions of $1 \mathrm{ml}$ were collected at a flow rate of $0.5 \mathrm{ml} / \mathrm{min}$. Fractions no. 9 contained electrophoretically pure crocodile transferrins.

\section{RESULTS AND DISCUSSION}

\section{Purification of transferrins from eggs}

The applied procedure allowed for simple and efficient purification of crocodile and python ovotransferrins. As a result, electrophoretically pure proteins were obtained. The presence of individual proteins during preparation was monitored by SDS/ PAGE. Initially, transferrins were identified on the basis of molecular mass.

Crocodile transferrins were purified from egg white in a four-step procedure including egg white lyophilisation, ammonium sulphate fractionation, anion exchange and hydrophobic chromatography. Lyophilisation of egg white followed by its suspension in $0.05 \mathrm{M}$ sodium phosphate buffer, $\mathrm{pH}$ 7.0, containing $0.15 \mathrm{M} \mathrm{NaCl}$ enabled the elimination of structural components, such as ovomucins. The relatively large protein loss at this stage indicates that a significant portion of soluble proteins was also entrapped within the insoluble pellet. Recovery attempts by pellet resuspension in a fresh buffer did not give satisfactory results. Ammonium sulphate fractionation allowed discarding the majority of the soluble egg white proteins in the first and second precipitation steps (30\% and 50\% salt saturation). Protein precipitated with $80 \%$ ammonium sulphate saturation was dissolved and loaded several times onto a MonoQ anion exchange column (Fig. 1A). Fractions (8-11) containing an $80-\mathrm{kDa}$ protein, as determined by SDS/ PAGE (Fig. 2), were pooled, dialysed against $0.05 \mathrm{M}$ sodium phosphate buffer, $\mathrm{pH} 7.0$, and $\left(\mathrm{NH}_{4}\right)_{2} \mathrm{SO}_{4}$ was added to a final concentration of $1.7 \mathrm{M}$. The protein solution was repeatedly applied onto a PhenylSuperose column (Fig. 1B). Starting from $6 \mathrm{~g}$ of lyophilised egg white, $7.5 \mathrm{mg}$ and $4.1 \mathrm{mg}$ of electrophoretically pure Cuban and Nile crocodile transferrins (fractions no. 9), respectively, were obtained (Fig. 2).

B)

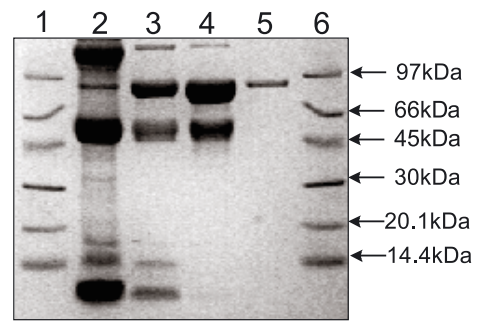

Figure 2. SDS/PAGE of samples from various steps of purification of crocodile ovotransferrins.

Cuban crocodile (A), Nile crocodile (B). Lanes 1 and 6: molecular mass markers; lanes 2: supernatants obtained from egg white lyophilisate suspended in $0.05 \mathrm{M}$ sodium phosphate buffer, pH 7.0, containing $0.15 \mathrm{M} \mathrm{NaCl}(12 \mu \mathrm{g})$; lanes 3: protein after $80 \%$ ammonium sulphate precipitation $(10 \mu \mathrm{g})$; lanes 4 : fractions pooled after ion-exchange chromatography $(8 \mu \mathrm{g})$; lanes 5: fractions 9 after hydrophobic chromatography $(2 \mu \mathrm{g})$. Proteins were stained with CBB R-250. The marker proteins (Amersham Pharmacia) were: rabbit muscle phosphorylase B (97 kDa), bovine serum albumin (66 kDa), chicken egg white ovalbumin $(45 \mathrm{kDa})$, bovine erythrocyte carbonic anhydrase (30 kDa), soybean trypsin inhibitor (20.1 kDa) and bovine milk $\alpha$-lactalbumin (14.4 kDa). 


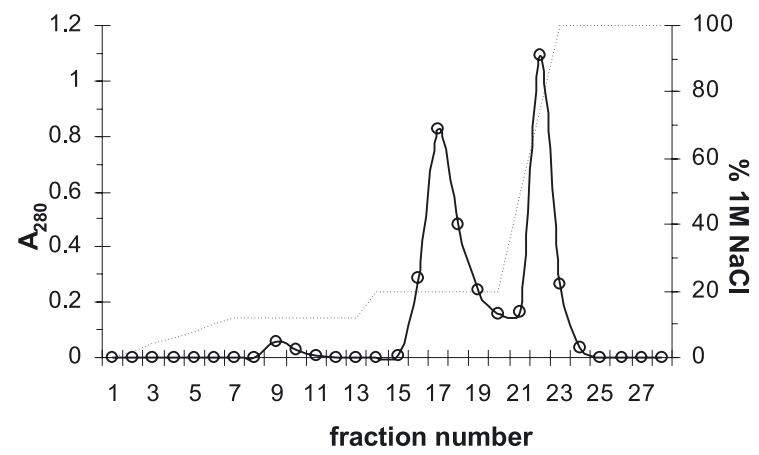

Figure 3. Ion-exchange chromatography on a MonoQ HR $5 / 5$ column of Burmese python egg proteins.

Each time, $5.1 \mathrm{mg}$ of protein in $0.02 \mathrm{M}$ Tris/ $\mathrm{HCl}$ buffer, $\mathrm{pH} 8.5$, was applied on a MonoQ column equilibrated with the same buffer. Proteins were eluted with a nonlinear gradient from 0 to $1 \mathrm{M} \mathrm{NaCl}(26 \mathrm{ml})$ at a flow rate of 1 $\mathrm{ml} / \mathrm{min}$ (fraction volume: $1 \mathrm{ml}$ ). Fraction no. 17 contained electrophoretically pure python transferrin.

Python ovotransferrin was purified in a threestep procedure including acidic extraction from whole egg content, ammonium sulphate fractionation, and anion exchange chromatography. Isolation was carried out from a mixture of yolk and white since the egg white content in Squamata eggs is very low and it is very difficult to separate it from the yolk. Mild acidic extraction followed by freezing, slow thawing, and filtration allowed discarding lipid egg content. Ammonium sulphate fractionation eliminated the great majority of egg proteins from the water soluble fraction. The protein precipitated with $80 \%$ salt saturation was dissolved and applied on a MonoQ anion exchange column (Fig. 3). As a result of multiple separations $4.6 \mathrm{mg}$ of electrophoretically pure snake transferrin (fraction No. 17) was obtained (Fig. 4).

The purity of the isolated proteins was confirmed by overloaded (10 $\mu \mathrm{g}$ per well) SDS/PAGE (Fig. 5).

\section{Amino-acid sequence analysis of purified transferrins}

The purified proteins were identified as transferrins by the N-terminal amino-acid sequencing. Sequences were determined for the Nile crocodile and python transferrins only (Fig. 6), since both crocodile proteins were isolated by exactly the same procedure. The obtained results confirmed that the purified proteins belong to the transferrin family.

Molecular mass, isoelectric points, and glycosylation

The transferrins' molecular mass values determined by SDS/PAGE and MALDI-MS and isoelectric points determined by chromatofocusing on a Mono P HR 5/20 column are shown in Table 1. Both crocodile transferrins exhibit very similar $\mathrm{pI}$ values (about 5.7), whereas the snake protein is more acidic ( $\mathrm{pI}=$

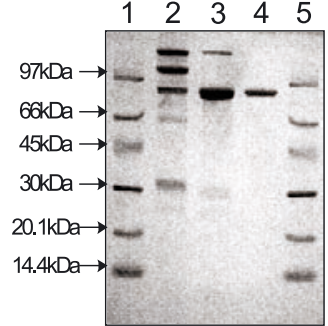

Figure 4. SDS/PAGE of samples from various steps of purification of Burmese python ovotransferrin.

Lanes 1 and 5: Mm markers; lane 2: supernatant obtained after acidic extraction $(12 \mu \mathrm{g})$; lane 3: protein after ammonium sulphate fractionation $(10 \mu \mathrm{g})$; lane 4: fraction 17 after anion exchange chromatography $(2 \mu \mathrm{g})$. The marker proteins are listed in the legend to Fig. 2.

Table 1. Molecular mass and isoelectric point (pI) values determined for the purified ovotransferrins

\begin{tabular}{llll}
\hline \multirow{2}{*}{ Transferrin source } & \multicolumn{2}{l}{ Molecular mass (Da) } & \multirow{2}{*}{ pI } \\
\cline { 2 - 3 } & SDS/PAGE & MALDI-TOF MS & \\
\hline Cuban crocodile & 86200 & 80744.08 & 5.72 \\
Nile crocodile & 87300 & 80215.71 & 5.69 \\
Burmese python & 83800 & 80113.60 & 4.55 \\
\hline
\end{tabular}

4.55). These values are significantly different from the values calculated for the amino-acid composition deduced from the available mRNA sequences (Nile crocodile transferrin EMBL ID: AM262323, $\mathrm{Mm}=74262 \mathrm{Da}, \mathrm{pI}=6.29$; Burmese python transferrin EMBL ID: AM262320, $\mathrm{Mm}=75514 \mathrm{Da}, \mathrm{pI}=$ 5.59). These discrepancies can be attributed to posttranslational modifications such as N-glycosylation. $\mathrm{N}$-glycan profiling on a GlycoSep C column (Fig. 7) shows the largest contribution of neutral oligosaccharides in Nile crocodile ovotransferrin and acidic disialylated glycans in the python protein. In crocodile transferrin the predominance of neutral chains (with $\mathrm{Mm}$ about $2 \mathrm{kDa}$ each) in the 6-kDa glycan moiety allows the assumption that all three potential N-glycosylation sites are occupied. The python protein glycan moiety has a lower molecular mass $(4.6 \mathrm{kDa})$ and is composed mostly of larger sialylated chains, indicating that probably only two of the three potential $\mathrm{N}$-glycosylation sites are actually occupied.

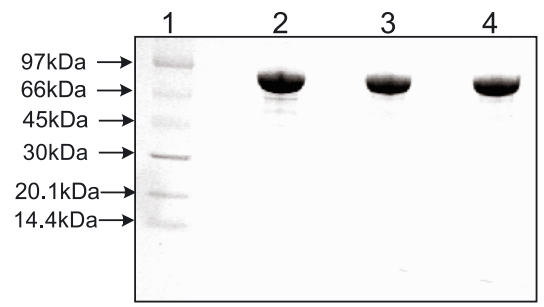

Figure 5. SDS/PAGE of purified ovotransferrins.

Lane 1: Mm markers; lane 2; Burmese python ovotransferrin $(10 \mu \mathrm{g})$; lane 3: Cuban crocodile ovotransferrin $(10 \mu \mathrm{g})$; lane 4: Nile crocodile ovotransferrin $(10 \mu \mathrm{g})$. The marker proteins are listed in the legend to Fig. 2. 
EMBL ID

\begin{tabular}{|c|c|}
\hline X02009 & CHICKEN \\
\hline$-\star \star$ & DUCK \\
\hline AJ 966469 & TURKEY \\
\hline AJ 786651 & OSTRICH \\
\hline AJ 786650 & $\begin{array}{l}\text { RED-EARED TURTLE } \\
\text { NILE CROCODILE } \\
\text { BURMESE PYTHON }\end{array}$ \\
\hline
\end{tabular}

Figure 6. Comparison of the N-terminal amino-acid sequences of crocodile and python transferrins with corresponding sequences of avian and other reptilian ovotransferrins.

Amino-acid residues identical in at least four sequences are shown in black boxes. Partial homology is indicated in grey boxes. Multiple sequence alignment was performed using the ClustalW program (http://www.ebi.ac.uk/clustalw). *For the duck transferrin, only the amino-acid sequence is available (SWISS-PROT P56410).

\section{Absorption spectra of iron-saturated transferrins and $\mathrm{pH}$-dependent iron release}

Transferrins saturated with ferric ions display a characteristic salmon-pink colour which is attributed to a charge transfer from tyrosine phenolate to the metal (Zak et al., 2002). Solutions of Fe-transferrins have an absorption minimum and maximum at about $410 \mathrm{~nm}$ and $465 \mathrm{~nm}$, respectively. An $\mathrm{A}_{280} /$ $\mathrm{A}_{\max }$ ratio near 22 indicates complete iron saturation and protein homogeneity (van Renswoude et al., 1982).

Absorption spectra over the range of 400-560 $\mathrm{nm}$ of the purified iron-saturated transferrins were recorded (Fig. 8). All three protein solutions display characteristic salmon-pink colour and have an absorption minimum at $410 \mathrm{~nm}$ and a maximum in the range of $460-480 \mathrm{~nm}$. The calculated $\mathrm{A}_{280} / \mathrm{A}_{465}$ ratios are 22.9, 23.0, and 24.9 for the $\mathrm{Cu}$ ban crocodile, Nile crocodile, and Burmese python transferrins, respectively. These values confirm the saturation of iron binding to the examined proteins, as well as their homogeneity. A decrease in the $\mathrm{A}_{465} / \mathrm{A}_{280}$ ratio at lower $\mathrm{pH}$ values confirms the $\mathrm{pH}$-dependence of the iron-release process (Fig. 9). Acidification causes protonation of the amino-acid ligands, resulting in a conformational change in the protein structure which leads to interdomain cleft broadening and ferric ion release (Bali et al.,

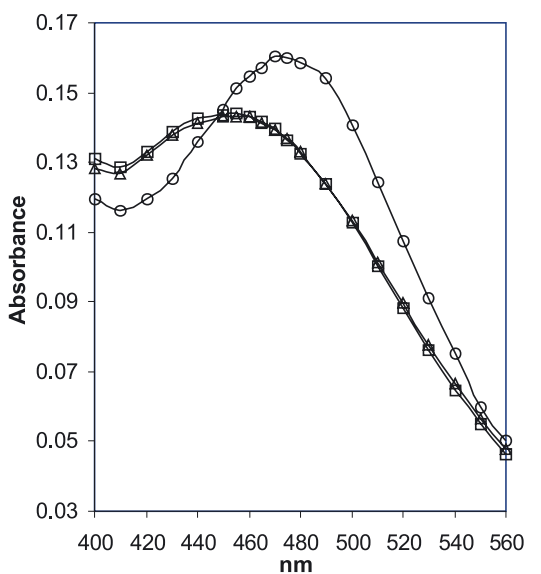

Figure 8. Absorption spectra of iron-saturated crocodile and python transferrins.

Spectra were measured over the range of $400-560 \mathrm{~nm}$ for solutions with a protein concentration of $1.9 \mathrm{mg} / \mathrm{ml}$. (O) Python transferrin; Cuban $(\square)$ and Nile $(\triangle)$ cocodile transferrin.

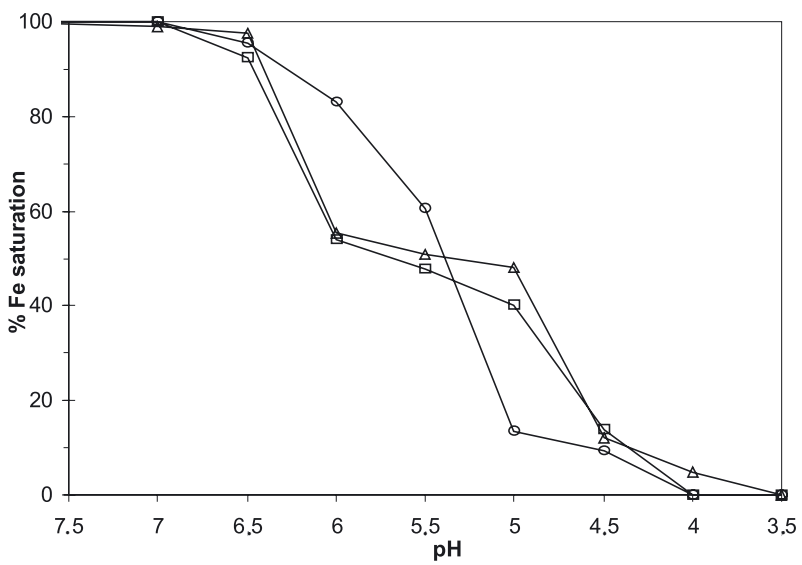

Figure 9. pH-dependent iron release from crocodile and python transferrins.

Percentage of iron saturation was estimated assuming the $\mathrm{A}_{465} / \mathrm{A}_{280}$ ratio at $\mathrm{pH} 8.5$ as $100 \%$ and at $\mathrm{pH} 3.5$ as $0 \%$ iron saturation.

2001; Zak \& Aisen, 2003). Sero- and ovotransferrin release iron in the $\mathrm{pH}$ range of 6-4, and the lactoferrins in the $\mathrm{pH}$ range of 4-2 (Ward et al., 1996; Baker et al., 2002). Despite identical iron ligands in both lobes, the rate of its release from the sero- and ovotransferrin $\mathrm{N}$-lobe is faster than from the C-lobe
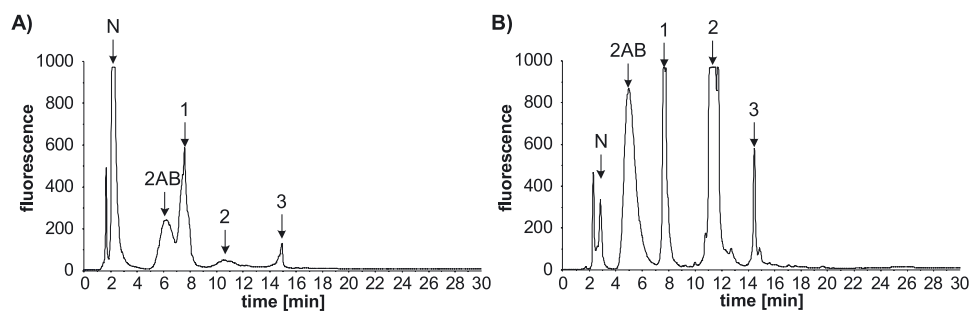

Figure 7. GlycoSep C separations of total $\mathrm{N}$-glycans released from Nile crocodile and Burmese python transferrins.

Glycans were fluorescently labelled with 2-AB, which is eluted in the second marked peak. The separation on the ion exchange column was performed at gradient conditions described in Materials and Methods. Elution positions of neutral sugars $(\mathrm{N})$ and glycans with 1 to 3 charged groups are indicated by arrows. 
(Mason et al., 2005). This difference results from the initiation of the conformational change by a "dilysine trigger" formed by two Lys residues located in the NI and NII domains (Dewan et al., 1993). On the other hand, the presence of analogous Lys residues in the $\mathrm{N}$-lobes of many lactoferrins does not promote metal release (Moore et al., 1997). In the C-lobe the "dilysine trigger" is not operational due to a substitution of one of the Lys residues (He et al., 1999). In mammalian serotransferrins there is a triad of residues (Lys, Arg and Asp) responsible for iron release from the C-lobe (Dewan et al., 1993). In ovotransferrins and lactoferrins, due to substitution in this triad, the mechanism of iron release from the C-lobe has to be different (Halbrooks et al., 2005). In the case of crocodile transferrins, the iron release process proceeds in a two-step manner, while snake transferrin releases iron in a monophasic way. This suggests that the difference in iron release between the $\mathrm{N}$ - and C-lobes is much less pronounced in python transferrin. A similar monophasic iron release by transferrin from rattlesnake (Crotalus viridis viridis) serum was observed (Welch, 1990). A substitution of Lys209 (numbering based on the chicken transferrin sequence) with an asparagine residue in all sequenced snake transferrins (EMBL IDs: AM262314, AM262316, AM262317), eliminating the "dilysine trigger" mechanism in the $\mathrm{N}$-lobe, can be the explanation for the monophasic type of iron release.

\section{CONCLUDING REMARKS}

In all sero- and ovotransferrins known a "dilysine trigger" mechanism is involved in iron release from the N-lobe of the protein. Different mechanisms are responsible for the C-lobe iron release. As a result, experimental profiles of iron release as a function of $\mathrm{pH}$ have a biphasic character for sero- and ovotransferrins (Baker et al., 2002). In lactoferrins the "dilysine trigger" in the N-lobe is not functional and the profile of $\mathrm{pH}$-dependent iron release is monophasic (Baker et al., 2002). Our analysis of transferrin cDNA sequences from different systematic groups of reptiles showed a unique substitution of the "trigger" Lys209 with Asn and probable inactivation of the "dilysine trigger" in the $\mathrm{N}$-lobe of snake transferrin. To confirm this we have purified ovotransferrins from two crocodile species (with preserved "dilysine trigger") and from Burmese python (without a functional "trigger") and compared their iron release profiles. The snake profile was monophasic, clearly indicating that the "dilysine trigger" mechanism in snake transferrin is not functional.

\section{Acknowledgements}

This project was supported in part by Grant No. 2 P04C 02327 from the Ministry of Education and Science.

\section{REFERENCES}

Aisen P, Enns C, Wessling-Resnick M (2001) Chemistry and biology of eukaryotic iron metabolism. Int J Biochem Cell Biol 33: 940-959.

Bailey S, Evans RW, Garratt RC, Gorinsky B, Hasnain S, Horsburgh C, Jhoti H, Lindley PF, Mydin A, Sarra R, Watson JL (1988) Molecular structure of serum transferrin at $3.3 \AA$ resolution. Biochemistry 27: 5804-5812.

Baker HM, Mason AB, He QY, Baker EN (2001) Ligand variation in the transferrin family: the crystal structure of H249Q mutant of the human transferrin N-lobe as a model for iron binding in insect transferrins. Biochemistry 40: 11670-11675.

Baker EN, Baker HM, Kidd RD (2002) Lactoferrin and transferrin: functional variations on a common structural framework. Biochem Cell Biol 80: 27-34.

Baker HM, Anderson BF, Baker EN (2003) Dealing with iron: common structural principles in proteins that transport iron and heme. Proc Natl Acad Sci USA 100: 3579-3583.

Bali PK, Zak O, Aisen P (2001) A new role for the transferrin receptor in the release of iron from transferrin. Biochemistry 30: 324-328.

Bigge JC, Patel TP, Bruce JA, Goulding PN, Charles SM, Parekh RB (1995) Nonselective and efficient fluorescent labeling of glycans using 2-amino benzamide and anthranilic acid. Anal Biochem 230: 229-238.

Ciuraszkiewicz J, Olczak M, Wątorek W (2006) Isolation, cloning and sequencing of transferrins from red-eared turtle, African ostrich, and turkey. Comp Biochem Physiol 144B: 301-310.

Dewan JC, Mikami B, Hirose M, Sacchettini JC (1993) Structural evidence for a $\mathrm{pH}$-sensitive dilysine trigger in the hen ovotransferrin N-lobe: implications for transferrin release. Biochemistry 32: 11963-11968.

Gianetti AM, Halbrooks PJ, Mason AB, Vogt TM, Enns CA, Björkman PJ (2005) The molecular mechanism for receptor-stimulated iron release from the plasma iron transport protein transferrin. Structure 13: 1613-1623.

Gomme PT, McCann KB (2005) Transferrins: structure, function and potential therapeutic actions. Drug Discov Today 10: 267-273.

Halbrooks PJ, Giannetti AM, Klein JS, Björkman PJ, Larouche JR, Smith VC, MacGillivray RTA, Everse SJ, Mason AB (2005) Composition of $\mathrm{pH}$-sensitive triad in C-lobe of human serum transferrin. Comparison to sequences of ovotransferrin and lactoferrin provides insight into functional differences in iron release. Biochemistry 44: 15451-15460.

He QY, Mason AB, Tam BM, MacGillivray RTA, Woodworth RC (1999) Dual role of Lys206-Lys296 interaction in human transferrin N-lobe: iron release trigger and anion-binding site. Biochemistry 38: 9704-9711.

Hentze MW, Kühn LC (1996) Molecular control of vertebrate iron metabolism: mRNA-based regulatory circuits operated by iron, nitric oxide, and oxidative stress. Proc Natl Acad Sci USA 93: 8175-8182. 
Kim H, Nakai S (1996) Immunoglobulin separation from egg yolk: a serial filtration system. J Food Sci 61: 510513.

Lambert LA, Perri H, Meehan TJ (2005a) Evolution of duplications in the transferrin family of proteins. Comp Biochem Physiol 140A: 11-25.

Lambert LA, Perri H, Halbrooks PJ, Mason AB (2005b) Evolution of transferrin family: conservation of residues associated with iron and anion binding. Comp Biochem Physiol 142B: 129-141.

Lee DC, McKnight S, Palmiter RD (1980) The chicken transferrin gene. Restriction endonuclease analysis of gene sequences in liver and oviduct DNA. J Biol Chem 255: $1442-1450$.

Mason AB, Halbrooks PJ, James NG, Conolly SA, Larouche JR, Smith VC, MacGillivray RTA, Chasteen ND (2005) Mutational analysis of C-lobe ligands of human serum transferrin: insights into the mechanism of iron release. Biochemistry 44: 8013-8021.

Moore SA, Anderson BF, Groom CR, Haridas M, Baker EN (1997) Three-dimensional structure of diferric bovine lactoferrin at $2.8 \AA$ resolution. I Mol Biol 274: 222-236.

Park I, Schaeffer E, Sidoli A, Barralle FE, Cohen GN, Zakin MM (1985) Organization of the human transferrin gene: direct evidence that it originated by gene duplication. Proc Natl Acad Sci USA 82: 3149-3153.

Schägger H, von Jagow G (1987) Tricine-sodium dodecyl sulfate-polyacrylamide gel electrophoresis for separa- tion of proteins in the range from 1 to $100 \mathrm{kDa}$. Anal Biochem 166: 368-379.

Valenti P, Antonini G (2005) Lactoferrin: an important host defence against microbial and viral attack. Cell Mol Life Sci 62: 2576-2587.

van Renswoude J, Bridges KR, Harford JB, Klausner RD (1982) Receptor-mediated endocytosis of transferrin and the uptake of $\mathrm{Fe}$ in K562 cells: identification of nonlysosomal acidic compartment. Proc Natl Acad Sci USA 79: 6186-6190.

Ward PP, Zhou X, Conneely OM (1996) Cooperative interactions between the amino- and carboxy-terminal lobes contribute to the unique iron-binding stability of lactoferrin. J Biol Chem 271: 12790-12794.

Welch S (1990) A comparison of the structure and properties of serum transferrin from 17 animal species. Comp Biochem Physiol 97B: 417-427.

Zak O, Ikuta K, Aisen P (2002) The synergistic anion-binding sites of human transferrin: chemical and physiological effects of site-directed mutagenesis. Biochemistry 41: 7416-7423.

Zak O, Aisen P (2003) Iron release from transferrin, its $\mathrm{C}$-lobe and their complexes with transferrin receptor: presence of $\mathrm{N}$-lobe accelerates release from C-lobe at endosomal pH. Biochemistry 42: 12330-12334.

Zor T, Selinger Z (1996) Linearization of the Bradford protein assay increases its sensitivity: theoretical and experimental studies. Anal Biochem 236: 302-308. 